\title{
科学者とは何か一その1
}

日本の科学と産業が縮みゆく理由

京都大学大学院 総合生存学館（思修館）山口栄 —

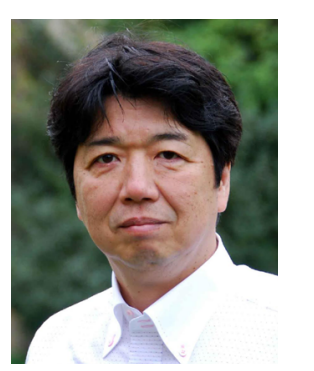

情報管理. 2015, vol. 58, no. 2, p. 135-138. doi: http://dx.doi.org/10.1241/johokanri.58.135

\section{沈みゆく船・日本の惨状：科学と産業とが同時 に縮む}

日本の科学とサイエンス型産業とが，ともに沈み ゆこうとしている。

飯嶋秀樹と私は，2004年を契機に物性物理学・物 質科学・分子生物学の分野で日本からの学術論文数 が単調に急減し，今もそれが続いていることを見 いだした1)。半導体産業やバイオ産業に直結してい るもつとも重要なこの3部門で，科学のアクティビ ティーが下がっているということだ。一体この原因 は何だろうか。

思い当たる原因として，2つの可能性がある。1つは， これらの分野における科学者たちの論文生産性が下 がったという可能性だ。この第1の可能性は，取りも 直さず研究ができなくなって論文が書けなくなった 科学者が増え始めたということになる。2004年とい えば，大学法人化が始まった年なので，この頃から 研究予算の重点配分が始まった。するとリサーチ・ ユニバーシティーと見なされていない大学において は研究予算の大幅な縮小があり，研究ができなくなっ た，という推測だ。しかし，化学など他の分野では， この急減現象は見られないことから，この第1の可能 性は考えにくい。

もう1つは，これらの分野において職業科学者の数 が減り始めた，という可能性である。この第2の可能 性を証明するには，博士後期課程の大学院生数の变 遷を調べればよい。幸い物理学については，そのデー タが存在し，たしかに1998年ころから物理学分野の
大学院生の数が減り始めていることがわかった。分子 生物学については，まだ定量的に調査できていない が，おそらくは同様の結果が得られると推測される。 大学院生がプロの研究者になるための期間は，おお むね6〜 8年である。とすると，2004年ころから学術 論文数が減少し始めたという事実をよく説明する。

では，なぜ物性物理学・物質科学や分子生物学の 分野で特異的に博士後期課程の大学院生数が減り始 めたのだろうか。それは，これらの分野で博士号を 取り，職業科学者になっても未来への希望がもてな いと，若者たちが考え始めたからではないだろうか。 これについては，緻密なインタビュ一調査をしなくて はならないものの，分子生物学の分野では，博士を 取るとむしろ就職口がなくなる，とはよく耳にする。

この第2の可能性が正しければ，1990年代後半を契 機として日本のエレクトロニクス企業や医薬品企業 が一斉に中央研究所を縮小し，その結果，民間企業 の科学者たちが書く論文数がつるべ落としに急減し ていった（つまり，民間企業の科学者がリストラさ れて研究できなくなった) 2)，3）いわゆる「中央研究 所の時代の終䮍」現象が，業態を超えて波及し，つ いにその影響がアカデミアに及んだ，ということに なる。だとすれば，企業が研究から撤退したことが， 日本の産業競争力を急落させるとともに，科学の競 争力まで落とさせていったという仮説が成立する。 創造的な若者たちに創造の場を与えることこそが， 国の責務である。日本という国が「沈みゆく船」になっ てしまったのは，1990年代の日本の産業政策の結果， 
その責務に思い至らず，無残にも創造的な若者たち がスポイルされていったためであると考えることが できよう。

\section{米国では新しいイノベーション・モデルが誕生}

ならば米国でも同じ現象が起きなかったのは，な ぜだろうか。むしろ米国では，1990年代以後，科学 も産業もますます盛んになっていった。落ちぶれて いったのは，日本だけだ。

というのも，「中央研究所の時代の終焉」現象は， 米国発の現象だからである。最初に1990年にAT\&Tべ ル研究所が研究から撤退することを決定。ほどなく 1991年にIBMが研究から撤退を始めた。世界のイノ ベーションを牽引してきたこの2つの機関の動向が， 世界中に波及した。それが「大企業中央研究所モデ ル」と呼ばれる20世紀イノベーション・モデルから の脱却であった。米国は，この20世紀イノベーション・ モデルから脱却したのち，新しいモデルを獲得した に違いない。一体，そのイノベーション・モデルとは， どのようなものだろうか。

最初に，その結論を述べておこう。

米国は，1990年代初頭にこの20世紀型イノベー ション・モデルから脱却したあと，開かれた「アメ リカ合衆国中央研究所モデル」と名付けることがで きる新しいイノベーション・モデルを見つけ出し た。それは，1982年に始めたSBIR（Small Business Innovation Research）プログラムと呼ばれる新しい 制度設計に端を発する。この制度こそが，無名の若 き科学者たちをイノベーターに仕立てることに成功 した。その科学者たちこそが新しい産業を起こし， 国を栄えさせたのである。

一方，同じように20世紀型イノベーション・モデ ルから脱却した日本は，この新しいイノベーション・ モデルに移行することができずに漂流した。なぜか。 それは，1999年にこの米国版SBIR制度をまねて日本 版SBIR制度を開始したものの，米国版SBIR制度の思想 的深淵をついに理解できなかったからである。その
結果，日本版SBIR制度は，浅薄な思想のもと単なる 従来型中小企業支援政策に成り果ててしまった。

なぜ米国版SBIRの思想的深淵を理解することがで きなかったのか。それは，本稿のタイトルにある「科 学者とは何か」という問いへの答えの中に隠れてい る。私は2011年3月，東日本大震災直後に起きた東 京電力福島第一原子力発電所の過酷事故をきっかけ に，そのことに気づいた。そこで急ぎ，物理学者か ら数学者，哲学者に至るまで12名からなる超域分野 (Trans-discipline) のチームを編成し，3年かけてこ の謎を解き明かした。そしてその謎を解き明かすプ ロセスと謎の解答を，『イノベーション政策の科学一 SBIRの評価と末来産業の創造』と題して，東京大学 出版会から2015年3月に出版した4)。本稿の以下は， この書籍のダイジェストである。

\section{米国版 SBIR とは}

米国版SBIR制度とは何か。その特徵をまとめてお こう。

第1の特徵は，米国連邦政府の外部委託研究 費（extramural research budget）の一定割合を スモール・ビジネスのために拠出することを義務 づけている点である。この義務化によって，国防 総省 (Department of Defense: DoD)，保健福祉 省 (Department of Health and Human Services: HHS)，航空宇宙局 (National Aeronautics and Space Administration: NASA)，エネルギー省（Department of Energy: DoE)，国立科学財団 (National Science Foundation: NSF）など11の省庁は，外部委託研究 予算の一定割合以上をSBIRに回さなければならない。 その割合は，1997～2011年度までは2.5\%。その後 毎年 $0.1 \%$ ずつ上げられて，2015年度には $2.9 \%$ となっ た。さらに2016年度には3.0\%，2017年度以後は3.2\% とすると定められている。

第2の特徵は，3段階の選抜方式で「賞金」（award） の授与者を決定するということである。第1段階 （フェーズl）は，アイデアの実現可能性を探索する 
フェーズであって，競争率6倍程度で選抜された企業 に対して最大 15 万ドルの「賞金」を約 6 月月〜 1年の 期間で拠出する。第2段階（フェーズII）は，技術の 商業化を試みるフェーズであって，競争率2倍程度で， フェーズに゙良い評価を得た企業を選抜し，最大150 万ドルの「賞金」を約 2 年の期間で拠出する。1社当 たりの平均「賞金」額は2012年度においては約89万 ドルであった。最後の第3段階（フェーズII）は，実 際に技術を商業化してイノベーションを成就させる フェーズであって，「賞金」はなく民間のベンチャー・ キャピタル (VC) を紹介する。さらにDoDやDoEな どの場合は，生まれた新製品を各省庁が政府調達し て，強制的に市場を創出する。「この世にないもの をあらしめた」のだから，市場は存在しない。だか ら政府が市場を創りだしてSBIR被採択企業の成長の きっかけとしているという思想である。

すなわち米国版SBIRプログラムとは，連邦政府と いう名の「目利き力」の高いエンジェルにほかなら ない。米国は，このプログラムで，21世紀に入って からは毎年1,500 2,000人に至る無名の科学者をべ ンチャ一起業家に仕立ててきた。かくて，過去30年 間で4万6,000社を超える技術ベンチャーが生まれ， ついに国家全体に開かれたイノベーション・エコシ ステムができあがった。それはポスト「大企業中央 研究所モデル」として創られた「アメリカ合衆国中 央研究所モデル」と呼ぶにふさわしい新たなイノベー ション・モデルとなった。

\section{日本版 SBIR とは}

対する日本は，中小企業技術革新制度（日本版SBIR 制度）を1999年2月から施行した。当初は，5省庁（通 商産業省，郵政省，科学技術庁，厚生労働省，農林 水産省）がこの日本版SBIRに参加した。その後2000 年度に環境省が参加し，2005年度に国土交通省が参 加して，現在では7省（経済産業省，総務省，文部科 学省，厚生労働省，農林水産省，環境省，国土交通省） が日本版SBIR制度に参加している。
この日本版SBIR制度の第1の特徵は，米国版SBIRと は異なって「政府の外部委託研究予算の一定割合を スモール・ビジネスのために拠出することを義務づ けていない」という点である。法律で定められてい ないため，参加するかしないかは省庁の任意であっ て，その額は，2009年度こそ交付実績1,185億円と米 国版SBIRに迫る勢いであるものの，通常は200～400 億円程度と米国版SBIRの5分の1から10分の1である。 しかもその実態は，すでに存在する補助金制度に後 から「日本版SBIR」のレッテルを単に貼るにすぎな い。したがって交付金は精算払いがほとんどで，会 計検査院の検査も厳しいゆえ，米国のように「賞金」 と呼ぶには程遠い。

第2の特徵は，やはり米国版SBIRとは異なって「多 段階選抜制度ではない」という点である注1)。もとよ り大学で生まれた科学知を技術にまで昇華させ，そ れをもって新産業を創り出すという高邁な思想がな いので，科学者をイノベーターにするための育成プ ロセスは存在しない。さらに政府による強制調達も なく、VCを紹介することもない。こうして日本版 SBIRの被採択者は，ほとんどが既存の中小企業になっ てしまった。

第3の特徵は，解決すべき具体的課題（topic）が 与えられないという点である。米国版SBIRにおいて は，粒度の細かい具体的課題が出される。たとえば， 「超高温で作動するセラミックのマイクロ波プロセッ サーを創れ」であるとか，「樹林地帯におけるRFセン シング・トラッキングを創れ」，さらには「光スイッ チを用いたイオンチャネル創薬を発見せよ」など。

\section{山口＼cjkstart栄一(やまぐち えいいち)}

京都大学大学院 総合生存学館 (思修館) 教授。 1955年，福岡市生まれ。東京大学理学部物理学科卒業。 同大学院理学系研究科物理学専攻修士課程修了, 理学 博士 (東京大学)。米国ノートルダム大学客員研究員， NTT基礎研究所主幹研究員，仏国IMRA Europe招聘研究 員，経団連21世紀政策研究所研究主幹，同志社大学大 学院教授，英国ケンブリッジ大学クレアホール客員フェ ローなどを経て，2014年より現職。 
それは，今この世にないものをあらしめるべく挑戦 せよという指令だ。科学行政官のミッションは，そ のような未来産業創造に向かうべき課題をつくり， それを申請者に提示することである。しかし日本で は，グリーン・イノベーションに資すること，とい う枠組みは提示されても，具体的課題は提示されな い。そもそも未来の産業を創るような課題を思いつ く「目利き力」が行政側に存在しない。科学行政官 制度がないからである。
こうして結局のところ日本版SBIRは，米国版SBIRと は似て非なるものになってしまった。そもそも米国 版SBIRとは異なり，日本版SBIRに採択されても名誉 にはならない。実のある効果を伴わないので，話題 にもならない。採択する側もされた側も，膨大な事 務負担を伴う形式的で意味の乏しい施策になってし まった。

（次回［2015年9月号］に続く）

\section{本文の注}

注1）唯一，経済産業省傘下の新エネルギー・産業技術総合開発機構（NEDO）が実施しているSBIRプログ ラムの1つ「新エネルギーベンチャー技術革新事業」のみが2段階選抜方式である。

\section{参考文献}

1）飯嶋秀樹, 山口栄一. “日本の論文数はなぜ減少したのか：その前に「なぜ論文を書くのか」”. 研究・技術計 画学会2014年大会.

2) 山口栄一.イノベーション：破壊と共鳴. NTT出版, 2006, 312p.

3）山口栄一."ブレークスルーのイノベーション理論：メモリーデバイス産業は「ムーア以後」にどう立ち 向かうか?". 応用物理. 2010, vol. 79, no. 12, p. 1077-1083.

4) 山口栄一編. イノベーション政策の科学：SBIRの評価と未来産業の創造. 東京大学出版会, 2015, 348p. 